\title{
What the largest tadpole feeds on? A detailed analysis of the diet composition of Pseudis minuta tadpoles (Hylidae, Dendropsophini)
}

\author{
SÔNIA HUCKEMBECK ${ }^{2}$, LÍVIA T. ALVES ${ }^{2}$, DANIEL LOEBMANN ${ }^{2}$ and ALEXANDRE M. GARCIA ${ }^{1}$ \\ ${ }^{1}$ Instituto de Oceanografia, Universidade Federal do Rio Grande/ FURG, \\ Av. Itália, Km 8, Carreiros, 96203-900 Rio Grande, RS, Brasil \\ ${ }^{2}$ Instituto de Ciências Biológicas, Universidade Federal do Rio Grande/ FURG, \\ Av. Itália, Km 8, Carreiros, 96203-900 Rio Grande, RS, Brasil
}

Manuscript received on May 18, 2015; accepted for publication on August 10, 2015

\begin{abstract}
We analyzed the diet of 25 individuals of Pseudis minuta tadpoles which consisted in debris with more than $30 \%$, follow by diatoms, euglenids, green algae, and desmids. With regard to the feeding strategy, $P$. minuta tadpoles are generalist consumer. The negative correlation between the abundance of items in the digestive tract and the mouth width indicate an effect of metamorphosis on the diet.
\end{abstract}

Key words: algae, anuran, metamorphosis, trophic ecology.

\section{INTRODUCTION}

Neotropical frogs from the genera Pseudis encompass those hylids species most adapted to live in aquatic environments (Huckembeck et al. 2014). The most conspicuous feature of this genus, however, is the fact their tadpoles are much larger than adults and for this reason they are known as Paradoxal frogs (Garda and Canatella 2007). Currently, seven Pseudis species are recognized and widely distributed from South America to the east Andes, being Pseudis minuta Günther, 1858 the most austral species with a widely distribution along the Pampa Domain of Argentine, Brazil and Uruguay (Frost 2016).

Although the genus Pseudis is relatively well studied with regards to reproduction, ecology and

Correspondence to: Sônia Huckembeck

E-mail: sohuckembeck@yahoo.com.br taxonomy (e.g. Barrio 1970, De Sá and Lavilla 1997, Kwet 2000), there is little information on the trophic ecology of the larvae (Arias et al. 2002, Vera-Candioti 2007). Consequently, little is known about the role species of tadpoles in aquatic environments (Santos et al. 2016).

Additionally, there are no studies on potential diet shifts during the development of Pseudis tadpoles. Hence, there is a gap in knowledge of the trophic ecology of Pseudis minuta tadpoles, which only their morphological description and habitat utilization is currently known (De Sá and Lavilla 1997). Information on the trophic ecology of $P$. minuta tadpoles will contribute to the knowledge of the natural history of the species and help to understand its functional role in the ecosystem during the pre-metamorphic phase. Thus, the goal of this study was to analyze the diet composition during the development of P.minuta tadpoles. 
The study was carried out on a wetland area with ephemeral water body $\left(31^{\circ} 06^{\prime} 88.7^{\prime \prime}\right.$, $50^{\circ} 51^{\prime} 30.6$ "W) at the Lagoa do Peixe National Park (LPNP), which is located in Rio Grande do Sul state, southern Brazil. Vegetation was dominated by Poaceae family grasses, a few shrubs and species of macrophytes (see Huckembeck et al. 2014). Pseudis minuta tadpoles were collected in April 2009 by dip nets employed randomly along the water body and fixed in 10\% formalin. Collection permits were provided by ICMBio (number processes: 14523-2 and 14523-4).

For each specimen collected total length (TL) and mouth width (MW), in $\mathrm{mm}$, were obtained and their stages of development were classified according to Gosner (1960). Digestive tracts were dissected; the content was homogenized with $1 \mathrm{ml}$ of distilled water and placed in Uthermol chamber to analyze under an optical microscope with $40 \mathrm{x}$ magnification (Arias et al. 2002). Unidentified items, which formed a mass of organic material, were classified as debris.

We calculated frequency of occurrence (FO) and numerical percentage (NP) for food items found in each digestive tract. These parameters were used to calculate the alimentary index as proposed by Kawakami and Vazzoler (1980), with numerical abundance replacing volume. The alimentary index after the modification was $\mathrm{AI} i=\mathrm{F} i * \mathrm{NP} i / \sum(\mathrm{F} i * \mathrm{NP} i)^{*} 100$, where $\mathrm{AI} i$ is the alimentary index of item $i$ in the individual diet's; $\mathrm{F} i$ is the frequency of occurrence of item $i$ in the sample; and NPi is the numerical percentage of the item. Linear regression between the biometric data and the abundance of items for each specimen was made and Pearson coefficient $\left(\mathrm{R}^{2}\right)$ was calculated. Residual analysis was performed to investigate the suitability of the regression. Residual analysis met the normality (LT, Shapiro-Wilk $(\mathrm{W})=0.938$, $\mathrm{p}=0.163 ; \mathrm{MW}, \mathrm{W}=0.915, \mathrm{p}=0.05)$, independence (LT, Durbin-Watson $(\mathrm{DW})=1.811, \mathrm{p}=0.314 ; \mathrm{MW}$, $\mathrm{DW}=2.708, \mathrm{p}=0.963)$, and homoscedasticity (LT,
Breusch-Pagan $(\mathrm{BP})=0.444, \mathrm{p}=0.504 ; \mathrm{MW}$, $\mathrm{BP}=0.013, \mathrm{p}=0.907$ ) required for regressions. For those testes we used Past 3.0 software.

A total of 25 individuals between 25 and 44 Gosner stages were analyzed, resulting in 61 unique food items (Table I). According to the alimentary index (\%), debris and microalgae were the most significant food sources (see Table I). Some authors criticize the use of IAI alleging the possibility of an overestimation of small size and numerous items (Hyslop 1980). However, our results corroborate the analysis of stable isotopes presented by Huckembeck et al. (2014), which indicates that $P$. minuta tadpoles are primary consumers. In additional, the diet pattern found in P. minuta is in consonance with diet described to P. paradoxa tadpoles, which feed mainly on algae, invertebrates, plant remains and debris (Arias et al. 2002). On the other hand, Vera-Candioti (2007) described the diet of P. paradoxa mainly composed by insects follow by macrophytes. Our findings revealed a prevalence of benthic algae, suggesting that tadpoles are nektonics and fed on microalgae attached to aquatic vegetation and substrates in the water.

Significant values was found only in the relationship between the abundance of items and MW $\left(\mathrm{R}^{2}=0.49, \mathrm{t}=-4.541, \mathrm{p}=0.00\right)$. It was noted with an increase MW (stage 25, mean \pm standard desviation: $0.49 \pm 0.21 \mathrm{~mm}$ to stage 43 and 44 , mean \pm standard desviation: $4.75 \pm 0.66 \mathrm{~mm}$ ), there was a decrease in food intake in the late Gosner stages (42, 43 and 44). No significant relationship was observed between the abundance of food items and $\mathrm{TL}\left(\mathrm{R}^{2}=0.003, \mathrm{t}=-0.259, \mathrm{p}=0.79\right)$. According to Jenssen (1967), which studied ontogenetic diet shift in tadpoles of Lithobates clamitans, ontogenetic changes in diet composition of tadpoles occur due to anatomical and morphological modifications of digestive tract during their metamorphosis. The decrease in food intake observed in our study could be explained by the occurrence of the fasting 


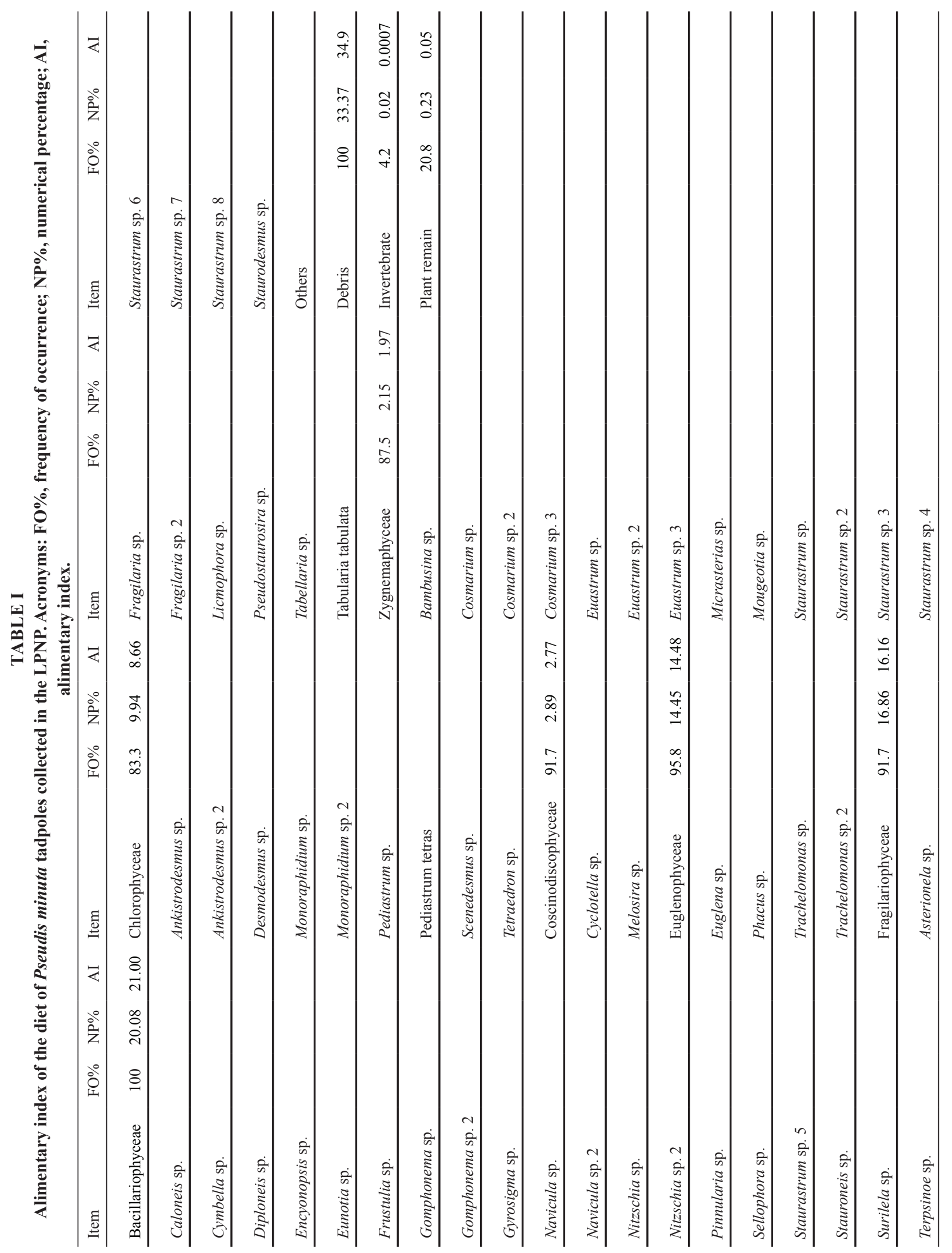


period in these stages, which, in L. clamitans, begin with the emergence of the forelimbs, followed by absorption of the tail (Jenssen 1967).

In summary, we conclude that Pseudis minuta tadpoles could be considered generalist consumer that primarily feed on algae. Furthermore, it is possible that the morphological changes occurring during advanced metamorphosis stages can influence food intake, therefore additional field and laboratory experiments should be performed to evaluate it.

\section{ACKNOWLEDGMENTS}

We thank Paulo César Abreu for his support and generous approval in loaning his microscope; and Stefanie Miranda for her assistance in sample processing. This work was supported by the International Foundation for Science (No. A/4419-1) and by Conselho Nacional de Desenvolvimento Científico e Tecnológico (CNPq) (No. 482920/2007-6). Sônia Huckembeck was funded by Coordenação de Aperfeiçoamento de Pessoal de Nível Superior (CAPES), and Alexandre Miranda Garcia was funded by a research grant provided by $\mathrm{CNPq}$ (305888/2012-9).

\section{REFERENCES}

ARIAS MM, PELTZER PM AND LAJMANOVICH RC. 2002. Diet of giant Pseudis paradoxa platensis (Anura, Pseudidade) from Argentina. Phyllomedusa 1: 97-100.
BARRIO A. 1970. Caracteres del canto nupcial de los Pséudidos (Amphibia, Anura). Physis 29: 511-515.

DE SÁ RO AND LAVILLA EO. 1997. The tadpole of Pseudis minuta (Anura: Pseudidade) an apparent case of heterochrony. Amphibia-Reptilia 18: 229-240.

FROST DR. 2016. Amphibian species of the world: an online reference. Version 6.0. Electronic database. New York (NY): American Museum of Natural History.

GARDA AA AND CANNATELLA DC. 2007. Phylogeny and biogeography of paradoxical frogs (Anura, Hylidae, Pseudae) inferred from $12 \mathrm{~S}$ and $16 \mathrm{~S}$ mitochondrial DNA. Mol Phylogenet Evol 44: 104-114.

GOSNER K. 1960. A simplified table for staging anuran embryos and larvae with notes on identification. Herpetologica 16: 183-190.

HUCKEMBECK S, LOEBMANN D, ALBERTONI EF, HEFLER SM, OLIVEIRA MCLM AND GARCIA AM. 2014. Feeding ecology and basal food sources that sustain the Paradoxal frog Pseudis minuta: a multiple approach combining stomach content, prey availability, and stable isotopes. Hydrobiologia 740: 253-264.

HYSLOP EJ. 1980. Stomach content analysis: a review of methods and their applications. J Fish Biol 17: 411-429.

JENSSEN TA. 1967. Food habits of the green frog, Rana clamitans before and during metamorphosis. Copeia 1967: 214-218.

KAWAKAMI E AND VAZZOLER G. 1980. Método gráfico e estimativa de índice alimentar aplicado no estudo de alimentação de peixes. Bol Inst Oceanogr 29: 205-207.

KWET A. 2000. The genus Pseudis (Anura: Pseudidae) in Rio Grande do Sul, southern Brazil, with description of a new species. Amphibia-Reptilia 21: 38-55.

SANTOS FJ, PROTÁZIO AS, MOURA CW AND JUNCÁ FA. 2016. Diet and food resource partition among benthic tadpoles of three anuran species in Atlantic Forest tropical streams. J Freshwater Ecol 31: 53-60.

VERA-CANDIOTI MF. 2007. Anatomy of anuran tadpoles from lentic water bodies: systematic relevance and correlation with feeding habits. Zootaxa 1600: 1-175. 